\title{
MEDYA VE KÖRFEZ SAVAŞI
}

\section{Ash ÖZKAYA*}

1990 yılının Ağustos ayında Irak'ın Kuvcyt'e girmesiyle birlikte ortaya çıkan gerginlik, 1991 yılının Ocak ayındá başta Amerika Birleşik Devletleri olmak üzere, Ingiltere, Fransa, Suudi Arabistan, Kuveyt, Misır ve Suriye'den oluşan ana koalisyon ortaklarının Irak'a müdahalesi ile savaşa dönüşmüş ve Körfez Savaşı olarak anılan bu savaş 1991 senesinin Mart ayında Irak'in yenilgisiyle sonuçlanmıştır. Haberlerin tarihte ilk defa Amerikan kaynaklı ve yoğun biçimde uydu bağlanuların kullanan CNN (Cable News Network) televizyonu tarafından ç̧ anlı olarak verildiği Körfez Savaşı iletişim çalışmaları alanında önemli bir yere sahiptir. Haberlerin ilk kez eş anlı olarak iletilmesinin yanı sıra Körfez Savaşı bilgisayarlar ve akıllı bombalar (smart bombs) ile savaşılan belki de 'ilk gerçck yüksck teknoloji savaşı' ${ }^{1}$ olarak tarihe geçmiştir.

Bu çalışmada ilk olarak iletişim çalışmaları alanındaki temel kuramsal yaklaşımlar gözden geçirilecek, daha sonra da Körfez. Savaşı bu kuramsal yaklaşımların ışığında incelenecektir.

\section{Kamusal Yaklaşımlar}

M. Ayşe Inal'ın 'Haber Ürctim Sürecine Farklı Iki Yaklaşım' isimli makalesinde tartış̧ığı gibi iletişim alanında çalışan araştırmacıların 'basın kuruluşları', 'haber' ve 'gazetecinin rolü' ile ilgili ön kabullerine baktığımızda, haber ve haber üretimi konusunda yapılan araştırmaları genel olarak iki gruba ayırarak incelemek mümkündür. Liberal çoğulcu yaklaşımı benimseyen araşırmacılar, bu toplum anlayışının özünde yatan 'ifade' ve 'basın ozgürlüğü' kavramlarını günümüzde kitle iletişim araçlarının işleyişini incelerken sıkça kullanılmaktadır. Bu yaklaşıma göre toplumda kitle iletişim araçları yasama, yürütme ve yargıya ek olarak 4. Gü̧̧ olma görevini üstlenebilir. 'Doğruya' ulaşma yetisine sahip profesyonel basın örgütleri çalışanların görevi rasyonel vatandaşlara enformasyon sağlayarak dünya ve/veya ülke olayları hakkında bilgilenmelerini ve 'doğru' karar vermelerini sağlamaktır. Gazeteci haber yaptığı olaya kendi değer yargılarından ve

\footnotetext{
* TODAIE Araştırma Görevlisi.

${ }^{1}$ Liebes (1992), s. 45.
} 
siyasal eğilimlerinden annarak 'nesnel' ve 'tarafsız' bir gözle bakarak, 'dengeli' ve 'yansız' haber üretebilme yetisine sahiptir. ${ }^{2}$

Çơ̌ulcu liberal 'geleneksel' yaklaşımı benimseyen araşurmacıların çalışmalar medya, haber ve haber iiretimi konularına eleştirel bir bakış açısıyla yaklaşan araşurmacılar tarafından eleştirilmiştir. Eleştirel bakış açısını benimseyen araştırmacılar basının toplumda bağımsız bir gü̧̧ olabileceği varsayımını, haberin 'gerçeğin' kendisi olduğu iddiasını ve basının profesyonel bir uzmanlık alanı olabileceği görüşünü sorgularlar. Eleştirel araşurmacılara göre medya 4. Güç olamaz. Bunun yerine kitle iletişim araçları varolan egemen ideolojik söylemlere özellikle zamansal sınurlılıklar ${ }^{3}$ yüzünden düzenli olarak yer vererek inanilurlıklanını kendi sőylemleri içinde tekrar kurarlar. Her ne kadar kitle iletişim araçlarının içeriklerinde ve ozellikle de haber metinlerinde bir nevi çeşitlilik varmış gibi gözükse de, aslında farklı söylemler güvenilir kaynakların söylemleri (güvenilir kaynaklar olarak 'uzman' olarak tanımlanan kişileri, çeşitli kurumların önde gelen kişilerini, iş adamlarını, hükümetten üst düzey yetkilileri ve örgütlenmiş baskı gruplanını sayabiliriz) içinde erir ve sonuç olarak metnin içinde iktidar sahibi kişi ve kurumlanın durum tanımlan on plana çıkar. ${ }^{4}$ Molotch ve Lester'ın haber teşvikçileri ${ }^{5}$, ve Hall ve arkadaşlarının birincil tanımlayıcılar (primary definers) ${ }^{6}$ olarak tanımladıklan güvenilir kaynakların söylemlerine düzenli ve ağırlıklı olarak yer verilmesinin yine Hall ve arkadaşlanı gibi eleştirel yaklaşımı benimseyen araşurmacılara göre önemli, haber üretim sürecinde son kertede medyanın egemen grupların tanımlarını yeniden kurmasıdır. Medya sadık bir biçimde toplumun kurumsal düzeni içinde varolan güç yapısını sembolik olarak yeniden üretir. Medya ve birinci tanımlayıcılar arasındaki bu yapısal ilişki, kaynak kişi ve kurumların söz konusu olayla ilgili başlıca yorumları (primary interpretation) kurmalarına izin verir. Bu yorum veya yorumlar problemin ne olduğu ile ilgili çerçeveyi çizerek takip eden tüm tarışmaların sınırlanını çizmiş olurlar. O halde medya basitçe haberleri yaratmaz veya dolaysız olarak 'yönetici sınıfın' ideolojisini yansıtmaz. ${ }^{7}$

Genel olarak eleştirel perspektifi teorileşmiş araştırmanın, bütünselci bir yaklaşımın ve makro sorunlara yönclimin, liberal perspcktifi de göreceli teorileşmemiş (görgül) araştırmanın, tikel bir yaklaşımın ve mikro sorunlara yönelimin karakterize ettiği tartışılmaktadır. Klasik çoğulculuk medyayı dördüncü bir ozcrk güç olarak yorumlamış, eleştirel görüş ise kitle iletişim araçlarına 'sınıf tahakkümünün

2 Inal (1994), s. 156, Robins (1993), s. 321.

${ }^{3}$ Çoğu katılmalı gözleme dayanan araştırmalarının sonuçlarına dayanarak zamansal ve mekansal sinırlılıklara (Fishman, M. (U.S., 1990) Manufacturing the News, University of Texas Press, sözünü eden Inal (1994), s. 170, Tuchman, G. (London, 1978) Making News: A Study in the Construction of Reality, Collier MacMillan Publications, sỏzunin eden Inal (1994), s. 167) önem veren fenomenolojistler eleştirel yaklaşıma yakın dururlar. Ancak fenomenolojistler ve eleştirel kuramcılar arasında metodolojik ve kurimsal farklılıklar vardır. Inal (1994), s. 159.

${ }^{4}$ Inal (1994), s. 157-159.

5 Molotch ve Lester (1974), s. 104.

${ }^{6}$ Hall ve arkadaşlanı (1978), s. 345.

${ }^{7}$ A.g.e. s. $340-342$. 
sürdürülmesinde rol oynayan idcolojik araçlar'8 olarak yaklaşmışur ${ }^{9}$ Liberal yaklaşımda merkezi sorun medyanın etkileri olmuş ve bu konudaki spekülasyonların ampirik testlerden geçmesi gerektiği savunularak içerik analizleri ayrıntılı bir şekilde geliştirilmiştir. ${ }^{10}$ Etki konusu ozzellikle Amerikalı iletişim araşurmacıları tarafından genel olarak insan doğasının ve toplumun davranış̧̧ı yorumlarına dayanarak formülleştirilmiştir. Bu türden çalışmaların amacı, insan ilişkilerinde kitle iletişim araçlarının oynadığı rol hakkında genellikle davranış̧ı bir kalıp içinde bir tür bilim benzeri bilgi üretmek olmuştur. ${ }^{11}$ Ancak medya mesajlan 'sembolik bir gösterge vasıtası ya da yapılanmış bir sőylem sıfatıyla geliş̧irilmemiştir. Liberal görüs medyanın başarılmış bir uylaşımı (achieved consensus) yansıtı̆ğını savunurken, eleştirel görüş medyanın onceden zaten başarılmış uylaşımı yansıtmak yerine şeylerin varolan yapısını meşrulaşuran durum tanımlarını yeniden üretme eğiliminde olduğunu savunur. Eleştirel görüşe göre medya açısından söz konusu olan bir şey yaptırmak için A'dan B'ye gönderilen mesaj-emirler değil, bütün ideolojik çerçeveyi biçimlendirmesidir. Medya çalışmalarında ideolojik boyutun gündeme gelmesiyle biçimlenen eleştirel görüşün cevaplamaya çalışuğı sorulardan ơnemlilerini ideolojik süreç nasıl iş̧ler ve mekanizmalan nelerdir, başat bir söylem nasıl olur da tek açıklama olma yetkisini kendisine tanır ve altematif tanımlar üzerinde koyduğu sının sürdürebilir, oluşturmuştur. Bu tarz sorular dikkatlerin önceleri tamamıyla teknik bir biçimde analiz edilen fiili medya pratiğinin farklı görünümlerine yönelmesini sağlamıştır. ${ }^{12}$

Curran'a göre çoğulcu geleneği benimscyen araşurmacılar toplumu, hiçbiri her zaman için egemen olmayan ve devamlı birbiriyle rekabet halindeki gruplar ve çıkarlar karmaşası olarak görürler. Bu anlayışta medya örgütleri devletten, kurumlaşmış baskı gruplarından veya siyasal partilerden önemli ölçüde bağımsız, sınırlı örgütsel sistemlerdir. Medya profesyonelleriyle diğer kurumlann temsilcileri arasında karşlıklı bir bağımlılık olduğu iddia edilir. Çeşitli kurumların temsilcileri görüşlerini kamuya iletebilmek için toplumun merkezi kurumlarına bağlıdırlar. Buna gore medyanın toplumda geniş izleyici kitlelerine ulaşabilmesi, ona toplumdaki merkezi kurumların karşısında en azından yarı özerk bir konum sağlar. ${ }^{13}$ Çoğulcu görüşe göre medyanın denetimi ozerk medya yönetimi seçkinlerinin elindedir ve bu seçkinler medya çalışmalarına önemli ölçüde esneklik derecesi tanırlar. ${ }^{14}$ Bu özerklik ve nesnellik ve tarafsızlık ilkelerine bağlılık iddiaları medyada üretim sürecinin nihai kontrolünün sorumlu olan medya profesyonellerinin clinde olduğu fikrini doğurur. Böylece medyanın her türlü yargıdan bağımsız bir biçimde, olabildiğince doğrı ve nesnel olarak çok yönlü gerçekliği yansıtması beklenir. ${ }^{15}$

${ }^{8}$ Ozbek (1991), s. 232.

${ }^{9}$ Curran (1994), s. 335-339.

10 Hall (1994), s. 58.

$11^{1}$ Fejes (1994), s. 251.

$12^{\text {Hall (1994), s. } 58,64,67,69,70,72-73 .}$

13 Ozbek (1991), s. 241.

${ }^{14}$ Curran (1994), s. 330.

15 Ozbek (1991), s. 240, 242. 
Çogulcuların aksine eleştirel görüşü benimseyen araşurmacılara göre medyanın denetimi giderek tekelci sermayede yoğunlaşmaktadır. Medya örgütlerinde çalışanlar özerk olduklann iddia etseler de as:linda egemen kültürün normlan içinde toplumsallaşmakta ve bu normlan içselleştirmekterirler. Eleştirel yorumculara göre sonuçia medya bir bütün olarak alındıgında egemen grupların çıkarlarına uygun yorumsal çerçeveleri nakleder vé medya izleyicileri bu çerçəveleri reddetmelerini mümkün kılacak altematif anlam sistemlerine ulaşamazlar. ${ }^{16}$

Çoğulcu görüşü benimseyen araşurmacıların davranış̧̧ı yöneliminin aksine medya, iletişim ve toplumsal iktidar arasındaki ilişkiyi incelemeye yőnelen ve büyük bolümú Ingiltere'deki ve Kıta Avrupa'sındaki araşurmacılardan oluşan eleştirel kuramcılar, sosyoloji ve tarih gibi çeşitli araşturma alanlarından esinlenmişlerdir. Çalışmalannda endüstrileşmiş kapitalist toplumlarnn Marksist bir eleştirisini temel alan ve Batılı kapitalist dünyanın sınıfsal olarak katmanlaşarak aynşmış toplumlarının ayakta kalabilmelerinde medyanın oynadığı rolü incclemeye çalışan bu eleştirel araştırmacılar arasında üç temel araşııma yaklaşımını tanımlamak mümkündür: Yapısalcı yaklaşım (mesela Althusser, Levi-Strauss, Lacan ve Gramsci'nin çalışmaları), Siyasal Ekonomi yaklaşımı (mescla Murdock ve Golding'in çalışmaları) ve Kültürel Çalışmalar (mesela Williams ve Hall'un çalışmaları) yaklaşımı. ${ }^{17}$

Birinci temel eleştirel yaklaşım olan yapısalcı yaklaşımı benimseyen araştırmacılar dilbilim, göstergebilim, antropoloji ve psikanalizde bulunan düşüncelerden esinlenerek, medyadaki anlamlandırma ve temsil sistemini ve süreçlerini incelemeye onem vermişlerdir. Amprik yapısalcı araşurma televizyon programlan, filmler, reklamlar ve buna benzer medya metinlerinin analizi üzerinde odaklanarak bireyin dünyayı tecrübe ettiği medya metinlerindeki üstü örtük düşünce kalegorilerini incelemeye çalışır. Yapısalcı çalışmalar, ideolojiyi medya endüstrileri ve toplumun ekonomik temelinin yansıması olarak ele alan geleneksel Marksist medya yorumlarındaki belli açıkları kapatmak konusunda olumlı rol oynamışlardır. ${ }^{18}$

Ideoloji üzerine yọ̆unlaşan yapılsalcı medya yorumlarını eleştiren siyasal ekonomiciler medya üretiminin ekonomik yapısı ve süreçleri üzerinde odaklanır ve medya endüstrilerinde görülen tekelleşmeye ve denetimin artmasına doğru giderek artan eğilime dikkat çekerler. Siyasal ekonomiciler ideolojinin hem ekonomik temelden daha ơnemsiz olduģunu hem de onun tarafından belirlendiğini iddia ederler. Medyanın gücünün ekonomik süreçler ve medya üretiminin yapılarında yatı̆̆ını söyleyen siyasal ekonomiciler altyapı-üstyapı modelini kullanarak medyanın, medyaya sahip olan ve kontrol eden sınıfların çıkarlarını meşrulaştıran yanlış bir bilinç ürettiğini ve bunu yaydığını öne sürerler. ${ }^{19}$

Eleştirel perspektiflerden üçüncüsü olan kültürel çalışmalar yaklaşımı ekonomik indirgemeciliğc karşı çıar. Bu yaklaşım kültürün, toplumsal varlık ve toplumsal bilinç arasında, altyapı-üstyapı ayrımının izin vereceğinden çok daha karmaşık bir diyalektik

\footnotetext{
${ }^{16}$ Curran (1994), s. 330.

${ }^{17}$ Fejes (1994), s. 252.

18 Orbek (1991), s. 245, Fejes (1994), s. 253.

19 Özbek (1991), s. 247, 248, Fejes (1994), s. 253.
} 
olduğunu ve bu diyalektiğin ơnemli bir dışavurumunun medya iletilerinde görülebileceğini öne sürer. Medya iletileri üzerinde odaklanması açısından yapıpsalcı yaklaşıma benzese de, yapısalcı yaklaşımın bu tür iletilere atfettiği özerkliğin aksine, kültürel yaklaşım medya içeriğinin ve eukisinin, medya iletilerinin üretildikleri ve algıladıkları toplumsal çevre tarafından biçimlendirildiğini varsayar. ${ }^{20}$

Eleştirel kuram içindeki bu bölünmeler Marksist kuramın değişik vurgularından kaynaklansalar da, temelde medya ilctilerini bir ideoloji olarak görme ve haberciliz̆i resmi kaynakların söylemlerinin yeniden üretildiği bir uğraş alanı olarak kāvrama eğilimindedirler. ${ }^{21}$

\section{Körfez Savaşında Medyanın Çerçevelendirme Mekanizmaları}

1991 senesinde çıkan Körfez. Savaşını çerçevelendirmede medya çeşitli mekanizmaları kullandı. Bunlardan bazıları şu ara başıklar altında incelenebilir.

- Koalisyon güçlerinin karşısındaki tarafın gösterilmemesi: Liebes'e 22 göre Körfez Savaşı bir savaşın karşı taraf gösterilmeden nasıl medyada yer alabileceğinin klasik bir örneğini teşkil eder. Savaş başlamadan önceki aylarda, televizyon izleyicileri Bağdat'taki yiyecek sıkıntıları, Irak tarafından tutulan Avrupalı rchineler gibi konulan televizyondan izleyebildiler. Ancak savaş başladığı zaman Saddam'ın kötülüğün sembolü olarak temsilinin dışında karşı taraf medyada yer almamaya başladı. Kara savaşı sırasında Irak askerlerinin çölde teslim olması ve hava akımları sırasında Irak askcrıcrinin sığınağının bombalanması gibi bir iki istisna olay dışında, haftalarca süren savaş boyunca yalnızca yanan petrol kuyuları ve petrole bulanmış kuşlar düşmanın cylemleri olarak medyada yer aldi.

Pck çok savaşıa, özcllikle de savaş sürerken, karşı taraf hakkınđa bilgi almanın zorluğu bilinir. Ancak bu savaş̧a kasıtlı olarak karşı tarafı göstermeme eğiliminin olması ihtimalı göz ardı edilcmeyccek kadar yüksck görünmektedir. Ister koalisyon, ister Irak tarafı olsun savaşın scbep olduğu insan ölümlcrine ve yaralanmalarına mümkün olduğu kadar az yer verilmesinin belki de bir ölçüde savaşın meşrulaşıırılmasında rolü olduğu iddia edilcbilir. Savaşs sırasında Irak'tan devamlı olarak haberleri ileten Amerikalı Peter Arnett'in az da olsa askerlerin sığınağının bombalanmasına ve bunun sonuçlanna yer vermesinin Amerikan hükümcti ve halk tarafından şiddetli tepki alması bu sonucu bir olçüde desteklemektedir. ${ }^{23}$ Philip Taylor da benzer bir şckilde koalisyonun 'kontrol edilen bir enformasyon ortami' yaratmasıyla, basiţ̧e neyin enformasyon neyin propaganda olduğunun ayırt edilmesinin imkansızlaşığını iddia ctmiştir. Taylor çalışmasında, koalisyonun birleşmiş askeri güçleri tarafından Saddam Husscin'in rcjimine karşı verilen savaşın kendisi ve medya tarafından göstcrilen savaş şcklinde iki savaşın olduğu sonucuna varmışur. ${ }^{24}$

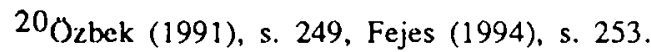

21 Inal (1994), s. 158.

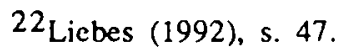

23 A.g.e. s. 47,48 .

${ }^{24}$ Robinson (1993), s. 322. 
Katz da Körfez Savaşıyla ilgili yaptığı 1992 tarihli çalışmada ${ }^{25}$ Liebes'in gơrüşlerine kaulmaktadır. Katz'a göre Körfez Savaşinın törensel (ceremonial) bir yanı vardır. Mesaj şuydu: 'bizimle kalın ve size (Saddam geri çekilmezse) Amerikan askerlerinin nasıl Orta Doğuya gittiklerini gőstereceł̌iz, bizimle kalın ve size (Irak'ın geri çekilmesi için verilen süre dolmuşsa) Amerikalıların nasıl ateş açuklannı gőstereceł̆iz.' Olayların bu şekilde dizile:jtirilmesi canlı bir televizyon savaşı için büyük bir izleyici kitlesi topladi. Ama aslında Katz'a göre seyirciler hiç savaş görmedi. Gördüklerimiz sürmekte olduğu sర̋ylenen bir savaşın sadece bazı yőnleriydi. Irak hudutlanna yığılan askerleri ve koalisyon güçlerinin ve de ozellikle Amerika'nın teknolojik üstünlügüünü gördük. Savaş esnasında üst düzey sözcülerin hatta daha sık olarak üst düzey ordu yetkililerinin neler olduğunu açıklamak amacıyla verdikleri basın toplanulanını gördük. Tankları, füzeleri, akıllı bombalan ve diğer askeri araçları gördüysek de onlanı eylem sırasında ya hiç görmedik ya da çok nadir gördilk. Sanki bir karşı taraf yoku. Bağdat'taki çaulardan haber ileten Amerikalı muhabirler (özcllikle de Peter Arnett) vardı. Fakat bunlar bir araya getirilmesi oldukça zor olan bağlantısız enformasyon parçalarıydı. Haber değil ama anında iletilen 'yorumsuz enformasyon, enformasyonsuz yorum' vardi. Enformasyonu sağlayacak CNN, yorumları yapacak uzmanlar vardı. Neredeyse tek görebildiğimiz veya duyabildiğimiz koalisyon güçlerinin bombalarının kendi askerleine, hemen hemen hiç bir sivile ve Irak'ın altyapısına zarar vermeden hedefini vurduğuydu. Bazen gökyüzünün sanki şehrin kendi ışıklan veya havai fişekler aydınlatıyormuş gibi aydınlandıgıını gördük amáı bir savaş görmedik. Düşmana verilen zarardan hemen hiç bahsedilmedi. Insanlar televizyonda savaşı seyrederken gerçekleri gördüklerini sandı ama Körfez Savaşı belki de tarihıte hakkında en az şeyi bildiğimiz savaş oldu. ${ }^{26}$

- Şiddet ve acı içeren sahnelere yer verilmemesi: Yukarıda da değinildiği gibi, Körfez Savaşında koalisyınun birleşmiş askeri gücünün ve özellikle de Amerika'nın askeri alanda teknolojik üstünlügüne yer verilse de, bu yok edici teknolojinin insani sonuçlari mümkün olduğunca gösterilmemiş ve sanki bir bilgisayar oyunu oynanıyormuş izlenimi yaratılmışur. Askєri merkezlere verilen zararlardan grafiksel olarak bahsedilmiş ve olen veya yaralananlara medyada neredeyse hiç yer verilmemiştir. Savaş uzaktan, izleyicilerin sıcak ve güvenli oturma odalarından duygusuz bir şekilde eğer bir bilgisayar oyunu izlenir gibi değilse bir "film" 27 izlenir gibi izlenebilmiştir. Yukarıda da belirtildiği gibi, nadiren bir iki olayla ilgili şiddet sahneleri medyada yer aldığında, savaşın insanlan öldürdügü insanlara haturlatılmış ve ne liderlerin ne de kamunun bu gerçeği görmek

25 Katz (1992), s. 8.

${ }^{26}$ Said (1993), s. 366.

${ }^{27}$ Gerbner, George (U.S., 1992) Persian Gulf War, the Movie, Triumph of the Image: The Media's War in the Persian Gulf, a Global Perspective kitabının içinde, Mowlana, Hamid-Gerbner, George-Schiller, Herbert I (Eds.), Boulder, CO: Westview Press, sözünu eden Kenney (1994), s. 100. Gerbner'e göre, Körfez Krizini bir film gibi izledik. Başlangıçta belirsiz olan bazı noktalar vardı ancak kısa zamanda iyi adamlann kötüleri a1! edeceği anlaşıldı. Tek taraf senaryonun her an değişebilmesi ihtimaliydi. Bunun yanında, aynen bir filmde olduğu gibi, Körfez Savaşını televizyonda izleyişimiz oyle hızlı oldu ki, tarihsel anlamları, alternatifleri veya uzun dönem sonuçlan düşünmeye vaktimiz olmad. Sonuçta Körfez. Savaşı upkı bir kaç ay önce seyredilen bir film gibi unutulmaya yüz tuttu. Cumings, Bruce (New York, 1992) War and television, Routledge, Chapman \& Hall, sỏzünı eden Kenney (1994), s. 101. 
istemedikleri ortaya çıkmıştır. ${ }^{28}$ David Morrison 1992 tarihinde yaptığı Televizyon ve Körfez savaşı' isimli çalışmasında, Ingiltere'deki televizyon izleyicilerinin büyük bir çoğunluğunun savaşın kanlı ve şiddet sahnelerini görmek istemediklerini bulmuştur ${ }^{29}$.

- Güçlerin eşit olduğu iddiası: Körfez Savaşında Batılı medyanın koalisyon güçlerinin karşısındaki tarafa mümkün olduğu kadar az yer vermesi ve hatta düşmanın kayıplarını olabildiğince az göstermesi, düşmanın gücünün önemsiz olduğu izlenimini yaratmamışur. Savaş esnasında izleyiciler saklanmaya çalışan Irak askerlerinin yakından çekilen yüzlerini görselerdi, koalisyon gü̧̧leri ve Irak arasındaki güç dengesizliğinden etkilenebilirlerdi. Bu şekilde yakın çekimlerin olmaması (ve olduğunda da Saddam'ın yok etmekte olduğu duygusallığı, saflığı ve doğayı temsil eden petrole bulanmış bir kuşun verilmesi) çoğu kez karşı tarafın aslında olduğundan daha fazla tehdit edici gücünün olduğu izlenimini yaratur. Körfez Savaşında bu şekilde güçlerin neredeyse eşit olduğu izlenimi yaratılmış ve 'süper gü̧̧' (Amerika Birleşik Devletleri) tarafından askeri güçlerin harekete geçirilmesi meşrulaştırılmışur. Karşılıklı güçlerin bu şckilde eşitmiş gibi gösterilmesi, denge unsurunu sağlamışur. ${ }^{30}$

Körfez Savaşında bu şekilde bir mekanizmanın kullanıldığı Amerikan yŏnetiminin savaşı, yeni Hitler (Saddam Hussein) ve onun karşısında müttefik güçlerle birlikte bir Ikinci Dünya Savaşı çerçevesine oturtma çabasından bellidir. Dönemin Amerikan başkanı Bush'un çizdiği çerçeveye göre Irak bağımsızlığını hiçe sayarak komşu bir ülkeyi işgal etmiş̧ir. Irak kendi azınlıklarına karşı soykırıma giden faşist Almanya, Saddam yeni Hitler, ve Irak ordusu dünyadaki dördüncü büyük ordudur. Bu yalnızca karşıt ideolojilerin çatışması de ğil, iyinin kötüye karşı verdiği bir savaşur. Zaten Batı uygarlığının ve bölgedeki diğer devletlerin yaşamaya devam edebilmesi ve özgürlüğü için şarttur. Bu çerçevelendirme çabası medya tarafından da benimsenmiştir. Aynca Irak'ın kimyasal silah ve biyolojik silahlan üzerine savaş bittikten sonra dahi vurgu yapılmasıyla, Saddam'in ve Irak ordusunun aslında olduğundan daha güçlü olduğu izlenimi yaratılmıştır. Düşmanın gücünün üzerinde savaş bittikten sơnra dahi bu şekilde durulmasının, kazanılan 'zaferin' parlaklığına katkıda bulunduğu sőylencbilir. ${ }^{31}$

- Krizin kişiselleştirilmesi: Körfez Savaşında iki tarafın insanlı̆̆ına simetrik olmayan bir şekilde yer vermiştir. Toplum içindeki çauş̧malar dahi bu yanlılıkla karşı karşıya kalır. Mesela grevciler, Vietnam karşıt göstericiler ve kentli isyancılar gibi popüler olmayan protesto gruplan 'resmi söylemin sınırları' içinde ve düzeni bozucu eylemde bulunuyormuş gibi gösterilmişlerdir. Protesto gruplanna medyada az yer verilmesi bu grupların dikkat çekmek için şiddete başvurmalarına sebep olur. Körfez Savaşının medyadaki temsilinde başta Amerika olmak üzere koalisyon tarafı

${ }^{28}$ Licbes (1992), s. 48, Inal (1996), s. 105. Robins Körfez Savaşının, imgelerin video oyunları ve bilgisayar simulasyonlarında gördŭğumuz imgelere benzediği, acısız 'Nintendo Savaşi olarak adlandırılan yeni ve farklı bir televizyon savaşı olduğunu söylüyor. Baudrillard'n terimleriyle, Körfez Savışıla 'gerçekçi savaş' olgusunun yerini 'sanal savaş' (virtual war) alıyor ve ekran sonunda gerçekliğin yerine geçiyor. Robins (1993), s. 325, Said (1993), s. 365.

${ }^{29}$ Nossiter (1993), s. 328, 330. David E. Morrison'ın çalışmasıyla ilgili daha detaylı bilgi için bakınız Robins (1993), s 322, Kenney (1994), s 101.

$30_{\text {Liebes (1992), s. } 49 .}$

${ }^{31}$ Liebes (1992), s. 49 , Katz (1992), s. 6, 7. 
kişileştirilmiştir. Iraklılara mümkün olduğu kadar görüntülerin içinde yer verilmezken, Amerikalılar her yerdedir. Pilotların görevlerini yerine getirmeden önce ve getirdikten sonra nasıl duygularını belirtliklerini, Suudi Arabistan çölünde görevli koalisyon güçlerinin personelini, çöl ve evleri arasında iletişim kurmaya çalışan ailelerin görüntülerini hepimiz izlemişizdir. Savaşta koalisyon tarafı medyada yer alan esas taraf olmakla kalmamış, kişileştirilen ve insancıl yönüne vurgu yapılan tek taraf olmuştur. ${ }^{32}$

Körfez Savaşında kişiieştirme sürecinin bir diğer yönü, Amerikan ve Irak liderlerine nasıl yaklaşıldığıına bakılınca görülcbilmektedir. Dönemin Amerika başkanı Bush, savunma bakanlığı sözcüsü ve General Schwartukopf düzenli olarak açıklama yapmak, bilgi ve güvence: vermek amacıyla medyada yer almıştır. Öyle ki savaşın özellikle de üst düzey askeri yetkilisi olan General Schwartzkopf aracılığıyla kişileştirilmesi, neredeyse savaşın onun savaşı olduğı havasını yaratmış ve Schwartzkopf savaş süresince özellikle de tclevizyonda hakim karakter haline gelmiştir. ${ }^{33}$ Oysa karşı taraftaki tek kişi 'Kuveyt'e tecavüz eden' 'Bağdat'ın kasabı, deli adam' Saddam ${ }^{34}$ olmuştur.

Bunların yanında, medyanın Körfez Savaşını temsilinde, eleştirel görüşlere yer vermeme eğilimi görülmüßştür. Krizin ilk hafıalarından sonra, medya savaş karşıtı hareketlere ve eleştircl uluslararası siyaset uzmanlarının görüşlerine yer vermemiş̧tir. Görüşlerine yer verilen kişiler Orıa Doğu konusunda uzman olduklaṇ varsayılan ancak Arapların yalnızca güç kullanmakıan anlayan insanlar olduğunu, şiddetin ve gaddarlığın Arap uygarlığının bir parçası olduğunu, Islam'ın hoşgörüsüz, fanatik, ayırımcı, kadının özgürlüğünü kısıtlayan, orta çağa ait bir din olduğunu belirten kişiler olmuştur. Bağlam, çerçeve ve taruşmaların küulması bu fikirlerle sinırlandırılmışur. ${ }^{35}$

- Bağlamın oluşturulması: Amerikan yönetimi ve medyası körfezdeki savaşla ilgili bağlamın büyük bir bölümünü daha çok önceden, Irak'a karşı harekete geçilip geçilmemesi ve diğer ülkelcrin destç̆inin nasıl alınabileceği tartışılırken oluşturmuştur. Gerginlik tırmandıkça, coğrafi politik bağlamdan askeri bir müdahalenin acil olduğu çerçevesine doğru bir kayı ol olmuştur. Gerginliğin dinamikleri (ültumatomlar, diplomasi, askerlerin transferi, kara savaşı için hazırlıklar) ön plana geçince, Saddam Husscin'in insan hakları ihlalleri ve hatta Kuveyt'in işgali merkezi konular olmaktan çıkmışur.

Körfez. Savaşında medya genel olarak savaşı bir suçluyu toplumun 'normal' çizgisine geri döndürmek için yapılan bir polis eylemi olarak tanımlamaktan kaçınmış (bu Irak'a eşit statü tanınm:ısını engeller ve vurguyu kỏıü olandan suçlu olana kaydırırdı) ve siyasi liderlerin Irak tehdidini olabildiğince yüksck gösterme tercihini benimsemiştir. ${ }^{36}$

Burada söylenmesi gereken Hackett'in de belirttiği gibi, bu çerçevelendirmeleri yaparken gazetecilerin belki de bilinçli dahi olmadıklarıdır. Gazeteciler belki de bilinçsiz

32 Liebes (1992), s. 50, 52.

${ }^{33}$ Liebes (1992), s. 52 .

${ }^{34}$ Said (1993), s. 358, Kellner, Douglas (U.S., 1992) The Persian Gulf TV War', Boulder. CO: Westview Press, sözünü eden Kenney (1994), s. 105.

35 Said (1993), s. $357,358$.

36 Liebes (1992), s. 53, 54, Katz. (1992), s. 6. 
olarak benimsedikleri, hedeflenen izleyicilere anlamı kılınabilmesi için haberlerin içinde yoğrulması gereken sosyal dünya ile ilgili varsayımlan yüzünden, bu tip çerçevelendirme mekanizmalan kullanmaktadırlar. Glasgow Üniversitesi Medya Grubu araşurmacılan, haberlerin ve egemen sosyal ideolojilerin ayrılmaz bir şekilde bağlantılı olduklannı sőylemektedirler. O halde egemen sosyal ideolojiler, haberlerin 'gerçekleri' (facts) ve izleyicilerin bu gerçekleri anlaması için gerekli olan geri plandaki varsayımlar arasında bir köprü işlevi görürler. ${ }^{37}$

\section{Körfez Savaşında Medyanın Dili Kullanımı}

Buraya kadar Körfez Savaşında medyanın çerçcvelendirme mekanizmalarından bahsedilirken vurgu telcvizyonun üzerinde olmuştu. Ancak bu noktadan sonra, Hall'n anlamlandırma politikaları tanımı temel alınarak Amcrikan yönetimi ve ordusunun Körfez. Savaşını tanımlayabilmek için dili nasıl kurduklan üzerinde kısaca durulacağından, vurgu gazetelere kayacakur.

Hall'a göre 'gerçek, gerçekliğin belirli bir tarzda kurulmasıydı'. Medya belirli bir tarzda kurulan gerçekliği yalnızca tekrar üretmekle kalmıyor, aynı zamanda da tanımlıyordu. Aktif olarak seçerek ve sunarak, yapılandırarak ve şekillendirerek, medya varolan bir anlamı ileımekıen öte, şeylerin anlam kazanmasını sağlıyordu. Hall'ın incelcdiği, idcoloji ve gücün nasıl bu gerçeklik kurgusunun bir parçası oldukları ve anlamlandırmanın nasıl politik mücadelenin bir alanı haline geldiğiydi. Medyanın rolü, egemen sınıf veya sinffların hegemonyasını yaratan ve devam ettiren sistemin ayrılmaz. bir parçası olması, egemen sınıfların medya üzcrindeki dirck kontrolüne dayanmadığı için, medyanın bağımsızlık iddiaları tümüyle hayali olarak algılanmamalıydı. Medya 'rızanın genel sınırlarına karşı duyarh olmalıydı ve zaten ancak bu sınırların içinde işleyerek meşru bir şekilde yaşamını sürdürebilirdi'. Böylece medya yansıtmanın yanında, nzanın üretimi ve şckillendirilmesi sürecinin bir parçası haline geliyordu. Bu şekliyle Hall'ın analizi, Körfez. Savaşının söylemini ve bu söylemin politik vurgularını anlamada yardımcı olabilecck bir çerçeve oluşıurmaktadır. ${ }^{38}$

Genel olarak Körfez Savaşında gazeteler bir dereceye kadar televizyonun yüreklendirici ve milliyetçilik duygulanını kabartıcı tonundan kaçınmaya çalışmı̧ ve önemli bir ölçüde başyazılara destek sağlamışlardır. Ancak gazetelerin 'düz' (straight) haberleri de savaş konusunda nza üretiminin bir parçasıdır.

Jansen'e göre Amerikan yönetimi ve ordu pek çok şekilde tartı̧̧maları şekillendirmede başarılıydılar. Konuyla ilgili çeşitli örneklerin verilmesi bu noktada açıklayıcı olabilir. 39 Mesela operasyonun adının 'Çöl Fırunası' konması tesadüfi değildir ve haber medyası bu ismin kullanılmasını sorgulamamıştır. Medyada sık sık Irak'ın Kuveyte karşı saldırgan tutumu yer alırken, Amerika Birleşik Devletleri'nin savaşı bir çöl fırtınası gibi süpürüp geçtiği ifadesi kullanılmıştır. Bu nitelemeler gelişigüzel yapılmamıştır ve iyi ile kötü hakkında yan anlamlar içerir. Eğer bir gelişigüzellik

${ }^{37}$ Hackett (1985), s. 263.

38 Jensen (1992), s. 21, Hackett (1985), s. 258. Haberi gerçekliğin bir tür 'inşası' olarak gören Tunchman'in görüşleri için bakınız lnal (1994), s. 166-168.

39 Jansen (1992), s. 22-25. 
olsaydı, pek çok Orta Doğu insanının ve dünyadaki ve Amerika'daki çok sayıda savaş karşıtı insanın düşündüğü gibi, Amerika'nın tutumunun saldırgan olduğu söylenebilirdi.

Benzer şekilde medya Amerikan ordusunun kampanyasını 'Kuveyt'i kurtarmak' için yapılan bir kampanya olarak tanımlamışur. Bu tip bir tanımlama Kuveyt'in bir zamanlar ठzgür olduğunu ve sonradan istila edildiğini ima eder. Bazı haber raporlan istila Oncesi Kuveyt'de demokrasinin olmadığına değinseler de, 'kurtulma' ve 'özgürlük' terimleri tutarlı bir şekilde Irak ordusuna karşı eylemi tanımlamak için kullanılmışı.ı. Başka bir bakış açısından, yine pek çok Orta Doğu insanının düşündügü gibi, belki de Körfez Savaşıyla yalnızca işgal eden Irak ordusunun yerini başka bir işgalci ordu, Amerikan ordusu aldı.

Amerikan yönetimi ve ordusunun anlamın kurulmasını nasıl başanyla kontrol ettiğine dair bir başka örnek de, medyanın Amerika'nın Irak'a karşı kullandığı yüksek teknolojiye sahip silahların kullanılmasını ve bu silahlann kullanılmasının Amerika'nın kendi ve koalisyon gücü askerlerinin kayıplarının azaltılmasında oynadığı rolü vurgulamasında görülebilir. Amerikan yönetimi Irak'ın yoğun şekilde bombalanmasının kısmen Amerikan hayatlarının kurtarılabilmesi için gerekli olan bir taktik oldụ̆u açıklamasını yapmıştır. Yüksek teknolojiye sahip silahların hayat kurtarabileceği düşüncesi silah endüstrisinin reklamlannda da yer almışur. Bu durumda, 'hayatlann' başarılı bir şekilde bu silahları kullanan Amerikan hükümeti ve üreten büyük firmalar tarafından tanımlandığı açıktır. On binlerce Iraklının hayatının bu silahlarla kurtarılmadığı gerçeği rahatlıkla göz ardı edilmiştir.

Anlamların kurulmasının kontrol edilmesinin önemi, diğer pèk çok şeyin yanında, 'acımasızlık hikayeleri' (atrocity story) ve 'kimyasal silah' terimlerinin kullanilmasında da görülebilmektedir. Savaş dönemi propagandasınđa, karşı tarafın eylcmlerini 'acımasızlık, gaddarlık eylemleri' olarak tanımlamak en bilinen taktiklerden biridir. Ancak ne zaman olüm ve acıya scbep olma bir gaddarlıkur ve ne zaman bu meşru veya en azından affedilebilir görülebilir? Körfez Savaşının medyadaki temsilinde bu hangi tarafın ölüme veya acıya sebep olduğuna dayandırılmışır. Iraklıların Kuveyt'teki eylemlerini 'gaddarlık' çerçevesi içine yerleştiren ordu ve yönetim ve bu çerçeveyi benimseyen medya (ki bu çerçeve Iraklıların Kuveytlilere karşı eylemlerinin mutlaka bir kısmını içerir), Kuveytlilerin Irak taraftarı veya sempatizanı olduklanını düşündükleri Filistinlilere karşı eylemlerini 'gaddarlık' olarak tanımlamamışlardır. Kuveyt'in Irak sempatizanı oldukları iddia edilen Filistinlileri üldürmesi, sanki savaş kayıpları gibi vurgulanmıs ve hatta Kuveytlilerin eylemleri topraklarına 'tecavüz' etmekte olan Irak'ın eylemlerine karşı intikam eylemleri olarak verilerek, en azından anlaşılabilir kılınmışur.

Kötủ düşman ve onun karşısında duran iyi kalpli gựçler resmi çizilirken, dilin kullanımındaki bu tür incelikler önemlidir. 'Gaddarlık' kelimesi öldürme eylemini misillemenin ahlaki açıdar meşru kılındığı yeni bir düzleme taşır. Mesela bir ülkenin kuvvetli bir şekilde saldınya maruz kalması, o ülkenin askerleri 'gaddar ve acımasız' olmaktan dolayı suçlu görülürlerse daha anlaşılabilir kılınabilir. Bu taruşma tabi ki Amerika'nın Irak'ı bombalamasının da bir 'gaddarlık' olup olamayacağı sorusunu göz ardı eder.

'Kimyasal silahlar' konusuna gelince, savaş boyunca Amerikan hükümeti ozellikle gaz olmak üzere Irak'ın kimyasal silahlanının tehdidini vurgulamış ve gaz kullanılmasının daha kuvvetli bir eylem için sebep olacağını açıklamıştır. Irak teslim olduktan sonra eğer 
Saddam Hussein kendi ülkesi içindeki isyanı basturmak için kimyasal silah kullanırsa Amerika tekrar saldırabileceği uyanısını yapmışur.

Irak'ın kimyasal silahlarının tehlikesi üzerine vurgu yapılması anlamların kurulması açısından onemliydi. Pek çok dünya ülkesinden insan, gazın I. Dünya Savaşında kullanıldığını ve korkunç olduğunu anımsıyordu. Kimyasal silahlar insanların uzerinde bırakığı bu etki üzerinde oynayarak, Amerikan hükümeti devamlı olarak Saddam Hussein'in kimyasal silah başlıklarının tehdidini vurguladı. Ancak, yönetimin konuyu çerçevelendirmesinde netliğe kavuşmayan iki noktadan biri neyin bir kimyasal silah olarak tanımlandığıydı. Amerikan ordusu tarafından kimyasal içerikli olduğu halde Irak'ta kullanılan napalm ve petrol bombalan, ordu ve medya tarafindan kimyasal silahlar olarak tanımlanmamışlardır. Ikinci olarak, kimyasal olan ve kimyasal olmayan silahlar arasında bir ikili karşıtlık yaratılmasıyla, ordu Irak'ın kimyasal silahlarınin farklı bir düzeyde tehdit oluş̧urduğu çerçevesini kurarak bu tehdide karşı Amerika'nın da farklı bir yanıt vermesi gerektiğini vurgulamıştır. Bu şekilde bir çerçeveleme, dikkatin Amerika'nın savaşta kullandığı kimyasal olmayan ama son derece yıkıcı olan silahlardan başka alanlara kaymasına neden olmuştur. Medya neden bu kimyasal olmayan silahların kimyasal olanlardan daha merhametli olduğu izleniminin yaratıldığı sorusunu sormamıştır.

Burada sð̋ylenmek istenen, Jensen'ın da belirtiği gibi, tabi ki savaşta kimyasal silahların kullanılmasının ciddi bir endişe yaratmaması gerektiği değildir. Önemli olan nokta, ordunun ve yőnetimin tanımları ve çerçeveleri kontrol ederek, sőylemi kendi amaçları doğrultusunda yönlendirmeleri ve haber medyasının da hemen hemen hiç bir noktada bu temel tanımları ve çerçeveleri sorgulamamasıdır.

\section{Sonụ}

Amerikan yönetimi ve ordusunun körfezde kazanılacak bir başarıyla kısmen de olsa Vietnam Savaşının izlerini silebilmeyi (Vietnam sendromu) amaçladığı iddia edilen ${ }^{40} \mathrm{Körfez} \mathrm{Savaşı,} \mathrm{yönetimin} \mathrm{ve} \mathrm{özellikle} \mathrm{de} \mathrm{ordunun} \mathrm{krizi} \mathrm{kontrol} \mathrm{ettiği} \mathrm{ve} \mathrm{sansür}$ uyguladığı (byle ki savaş alanına girişleri yasak olan gazeteciler canlı yayına geçmeden once merkezi arayarak haber almak durumunda kalmışlardı ${ }^{41}$ ) bir teknoloji savaşı olmus ve kontrol edilen imgeler uydular aracılığıyla eş anlı olarak tüm dünyada televizyonu olan herkes tarafından izlenebilmiştir.

Yukandaki tartışmalardan da anlaşılabileceği gibi, Körfez Savaşında medya, Hall ve arkadaşlanının 'birincil tanımlayıcılar' ve Molotch ve Lester'in 'haber teşvikçileri' olarak tanımladıklan güvenilir kaynaklara (ki savaş süresince bu güvenilir kaynaklar Amerikan başkanı, üst düzey sözcüler, askeri yetkililer, vb. gibi olmuştur) düzenli ve ağırlıklı olarak yer vererek, bu kaynak kişi ve kurumların savaşla ilgili başlıca yorumlanı kurmalarına izin vermis ve egemen kurumların tanımlarının yeniden üretilmesine katkıda bulunmuştur. Medyanın Körfez Savaşıyla ilgili haberleri verirken ağırlıklı olarak resmi

${ }^{40}$ Said (1993), s. 158, Katz (1992), s. 6.

41 Inal (1996), s. $105,106$. 
söylemin (official discourse) üzerinde durması ve eleştirel görüşleri göz ardı etmesi, haber metinlerinin farklı okumaları izin vermeyecek şekilde kapanmasına neden olmuştur. ${ }^{42}$

Körfez Savaşı liberal görüşü savunanların aksine, egemen söylemleri güçlülerin belirlediğini ve arada basit anlamda bir ckonomik ilişki olmasa da medyanın son kertede güçlülerin tanımlanını yeniden ürettiğini göstermiştir. Liberal görüşü savunanlar her ne kadar nesnelliğin ve tarafsızlığın, dengeli ve yansız haber üretmenin gazeteciliğin temel taşlan olduğunu iddia etseler de, Körfez Savaşında medya kontrol sürecinin bir parçası olarak hareket etmiştir.

Körfez Savaşında libəral anlayışın, insanlann yeterli bilgilendirildikleri takđirde 'dogrru' karar verme yetisine sahip rasyonel varlıklar oldukları iddiası da bir bakıma ve belli bir noktaya kadar haksız çıkanlmışur. Televizyon savaşı olarak adlandırılabilecek Körfez Savaşı boyunca, bu telcvizyon savaşının müptelası sürckli ve düzenli canlı yayınlar karşısında bir anlamda donakalmış ve cleştirel veya nesnel olarak düşünme yetilerini bir ölçüde yitirmişlerdir. ${ }^{43}$ Ama zaten egemen söylemlerin şekillendirdiği medyanın da en azından bir noktáya kadar ulaşmaya çalışığı bu değil midir?

\section{KA YNAKÇA}

Curran, James (1994), 'Kitlı Iletişimi Araşurmasında Yeni Revizyonizm: Bir Yeniden Değerlendirme Çabası', Medya, Iklidar, Ideoloji kitabının içinde, Çeviren: Mchmet Küçük, Aınkara, Ark Yayınları, 329-363.

Elliot, Philip-Murdock, Graham-Schlesinger, Philip (1986), 'Terrorism and the state: a case study of the discourses of television', Media, Culture and Socicty kitabının içinde, Curran, James-Collins, Richard-Garnham, Nicholas-Scannel, Pady-Schelesinger, Shilip-Sparks, Colin, London, Sage, 264-286.

Fejes, Fred (1994), 'Eleştirel Kitle lletişim Araşurması ve Medya Eukileri: Yok Olan Izleyici Sorunu', Medya, Iktidar, Ideoloji kitabın içinde, Çeviren: Mehmet Küçük, Ankara, A.rk Yayınevi, 251-269.

Hackett, Robert A. (1985), 'Decline of a Paradigm? Bias and Objectivity in News Media Studies', Mass Communication Review Yearbook, Cilt: 5, 251-274.

Hall, Stuart-Chas, Chritchei-Jefferson, Tony-Clarke, John-Roberts, Brian (1978), 'The social production of news: Mugging in the media', The Manufacture of News: Social Problems, deviance and the mass media kitabının içinde, Cohen, Stanley-Young, Jock (Eds.), London, Constable, 335-367.

${ }^{42}$ Elliot (1986), s. 268. 'Kapalı metinlerde' (closed text) altematif veya karşı görüşlerin sunulması ve incelenmesi söz konusu değildir. Ozellikle haber metinleri bu kategorinin içinde yer alır.

43 Taylor, Philip M. (Manchester, 1992) War and the Media: Propaganda and Persuasion in the Gulf War, Manchester University Press, sözünü cden Robins (1993), s. 322. 
Hall, Stuart (1994), 'Ideolojinin Yeniden Keşfi: Medya Çalışanlanında Baskı Altında Tutulanın Geri Dönüşü', Medya, lktidar, tdeoloji kitabının içinde, Çeviren: Mehmet Küçük, Ankara, Ark Yayınevi, 57-103.

Inal, M. Ayşe (1994), 'Haber Üretim Sürecine Farkı Iki Yaklaşım', Ankara Üniversitesi lletişim Fakültesi 1993 Yıllığı içinde, A.Ü. tletişim Fakültesi Yayınları No: 3, A.Ü. lletişim Fakültesi Basımevi 1994, 155-177.

Inal, M. Ayşe (1966), Haberi Okumak (Istanbul, Temuçin Yayınlarn).

Jensen, Robert (1992), 'Fighting Objectivity: The Illusion of Journalistic Neutrality in Coverage of the Persian Gulf War', Journal of Communication Inquiry, 16:1, 20-32.

Katz, Elihu (1992), 'The End of Journalism: Notes on Watching the War', Journal of Communication, 42(3), 5-13.

Kenney, Keith (1994), '(Mostly) Critical Vicws of Gulf War TV', Journal of Communication, 44(1), 100-105.

Liebes, Tamar (Mart 1992), 'Our War/Their War: Comparing the Intifadeh and the Gulf War on U.S. and Isracli Television', Critical Studies in Mass Communication, Cilt: 9 , No: $1,44-55$.

Molotch, Harvey-Lester, Marilyn (1974), 'News As Purposive Behavior: On The Strategic Use Of Routine Events, Accidents and Scandals', American Sociological Review, Cilt: 9, 101-112.

Nossiter, Tom (1993), 'Book Revicw', Media, Culture and Society, Cilt: 15, 329-330.

Özbck, Meral (1991), 'tletişim Araçları Üzerine Çalışma: Kuramsal Yaklaşımlar', Ankara Üniversitesi Iletişim Fakültesi 1989/1990 Yıllığı içinde, A.Ü. Iletişim Fakültesi Basımevi 1991, 229-253.

Robins, Kevin (1993), 'The war, the screen, the crazy dog and poor mankind', Media, Culture and Society, Cilt: 15, 321-327.

Said, Edward (1993), Culture and Impcrialism. (London, Vintage). 